„Tehetség, szorgalom, hivatás”

\author{
Tanulmánykötet
}

Kézirat lezárva: 2021. június 25. 
Kiadja:

a Magyar Rendészettudományi Társaság

Vám- és Pénzügyőri Tagozata

Szerkesztette:

Csaba Zágon és

Zsámbokiné Ficskovszky Ágnes

Felelős kiadó:

Szabó Andrea

ISBN: 978-615-81879-0-9

A mú szerzői jogilag védett. Minden jog, így különösen a sokszorosítás, terjesztés és fordítás joga fenntartva. A mű a kiadó írásbeli hozzájárulása nélkül részeiben sem reprodukálható, elektronikus rendszerek felhasználásával nem dolgozható fel, azokban nem tárolható, azokkal nem sokszorosítható és nem terjeszthetô. 
Szerzők

Lektorok

Lectori Salutem!

Tanulmányok

Christián László - Lippai Zsolt: Kakukktojás vagy új rendészeti alappillér?

Gonda Éva: Az Europol hospitáció hasznosítása a pénzügyi nyomozók képzése terén

Kakócz Krisztián - Vedó Attila: A toloncolás szabály- és szervezetrendszere a második világháború előtt

Kovács Gábor: A vezetői kompetenciák fejlesztésének lehetőségei a Rendészettudományi Kar hallgatóinak körében

Magasvári Adrienn: Egy új jogviszony „születése” - az adó- és vámhatósági szolgálati jogviszony vizsgálata ..

Molnár Katalin: Mi harminc? Tudománymetria helyett - Szerzőtársas játék................................ 87

Nyeste Péter: A modern bűnügyi hírszerzés modelljeinek fejlődése ............................................ 103

Pajor Andrea: Adóigazgatási tisztviselők képzése .

Sallai János - Borszéki Judit: Egy megvalósítható utópia? Közös munkanyelv keresése a nemzetközi rendőri együttmúködés kezdetén.

Suba László: Nyelvhelyesség a közszférában: Létkérdés vagy úri huncutság?

Szabó Andrea - Hájer Tamara: A vámfelsőoktatás uniós elismerési eljárásának elemei

Szlifka Gábor: Okos adózás, okos adóigazgatás - Minden ami okos, de mit is jelent pontosan?

Kutatási eredmények

Balla József - Kiss Lajos: A rendvédelmi szervező szakirányú továbbképzési szak indításának legfontosabb tapasztalatai.

Borzán Anita - Szekeres Bernadett: A digitalizáció hatása a gazdasági szakismeretek és a számvitel oktatására.

Duchon Jenő: Tanulási stílus és játékos típus összevetése felnőtteknél, az oktatási folyamat játékosítása céljából

Erdős Ákos - Somogyi Ágnes: Koffeinhasználat és koffeinhasználati zavar vizsgálata rendészeti hallgatók körében

Halasi Nóra: Feltáró kutatás a hivatástudat és motiváció jelentőségének vizsgálatára, a Hajdú-

Bihar Megyei Adó- és Vámigazgatóság személyi állományának összefüggésében 251 


\title{
Nyeste Péter*: A modern bűnügyi hírszerzés modelljeinek fejlődése
}

\begin{abstract}
Absztrakt
Tanulmányomban először a modern bűnügyi hírszerzés kialakulásával és fejlődésének rövid történeti áttekintésével foglalkozom. Röviden bemutatom a bűnügyi hírszerzés fejlődését a fővárosi rendőrség detektívtestületének létrejöttétől napjainkig. A tanulmányomban elemzem az új büntetőeljárási és ágazati törvények által kialakított gyökeresen új bűnügyi hírszerzési jogi környezetet. A jelenlegi bűnügyi hírszerzési szervezeti megoldásokat áttekintem és javaslatokat fogalmazok meg a nemzetközi bünügyi hírszerzési modellek alapján.
\end{abstract}

Kulcsszavak: bünügyi hírszerzés, birsz̨erzési modell

\begin{abstract}
First, I deal with a brief historical overview of the evolution of the development of modern criminal intelligence in my study. I will briefly present the development of criminal intelligence from the establishment of the Detective Department of Budapest Police to the present day. In my study, I examine the radically new criminal intelligence legal environment created by new criminal procedure and sectoral laws. I review current criminal intelligence organizational solutions and make suggestions based on international criminal intelligence models.
\end{abstract}

Keywords: criminal intelligence, criminal intelligence model

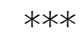

\section{Bevezetés}

A katonai hírszerzés, felderítés írásos nyomai már az Asszír Birodalom korából fennmaradt agyagtáblákról vagy az i.e. VI. században élt Szun-ce hadvezér írásaiból is megismerhetôk. Az ókori rómaiaknál már a reguláris erốk speciális egységeként, illetve civil ügynökökként tevékenykedtek a hírszerzők ${ }^{255}$ és szervezett formában folyó katonai hírszerző képzés nyomaira is bukkanhatunk.

Bűnügyi értelemben a felderítés szó jelentése eltitkolt vagy más okból látens, bűnügyileg releváns cselekmények, események megismerése, ismeretlen körülmények, részletek tisztázása, mások számára további eljárások és intézkedések érdekében is ismertté tétele. ${ }^{256} \mathrm{~A}$ bűnüldöző hatóságok bűnügyi hírszerző és nyomozástámogató tevékenysége csak a XVIII. században kezdett kialakulni Európában francia mintára Eugene Francois Vidocq párizsi titkosrendőrsége alapján.

\footnotetext{
${ }^{*}$ Nyeste Péter, Dr., rendőr őrnagy, adjunktus, Nemzeti Közszolgálati Egyetem Rendészettudományi Kar Bűnügyi, Gazdaságvédelmi és Kiberbűnözés Elleni Tanszék, https://orcid.org/0000-0002-2440-6414, nyeste.peter@uni-nke.hu

${ }^{255}$ BODA József - REGÉNYI Kund (szerk.): A hírszerzés története az ókortól napjainkig. Dialog Campus, Bp., 2019. p. 29.

${ }^{256}$ BODA József et al. (szerk.): Rendészettudományi szaklexikon. Dialog Campus, Bp., 2019. p. 185.
} 
A katonai, illetve nemzetbiztonsági felderítéshez hasonlóan a hazai bűnügyi hírszerzésnek is fokozatosan jöttek létre az elkülönült, specializált szervezeti elemei, humán és technikai erőforrásai és tevékenységének a módszertana, hírszerzési modellje.

\section{A hazai bűnügyi hírszerzés jellemzői a II. világháborúig}

Hazánkban a XIX. század végére alakult ki a bűnügyi hírszerzés a detektív testület létrejöttével. Már az 1870-es években megjelentek a bűnügyi hírszerzés kezdeteinek tekinthető hivatásos figyelők és „fedett nyomozók”, akiket az akkori szóhasználattal egyszerűen csak ,,rendőrkémeknek” neveztek. Ök voltak azok, akik egy-egy bűncselekmény esetében megfigyelték a pályaudvarokat, hajóállomásokat, az „értékesítési vonal” különböző színhelyeit és a nyomozások által látókörbe került gyanús személyeket. ${ }^{257}$

A Budapest-Fővárosi rendőrségen belül 1885. decemberében, 28 ideiglenes detektívvel szervezték meg először a detektív osztályt. Majd 1886-ban adták ki a bűnügyi hírszerző tevékenység első, belső jogi szabályozását, a detektívszabályzatot (majd 1890-ben a második, és 1893-ban a harmadik detektívszabályzatot). A detektívszabályzat szerint a detektívosztály a budapesti magyar királyi államrendốrség kisegitó egysége volt, feladata a főkapitányi hivatal, a kerületi kapitányi hivatalok, a bejelentési hivatal és a tolonckezelő hivatal munkájának támogatása a közrend és a közbiztonság fenntartása érdekében. A feladatellátás formái figyelo", megelo"zo" és felfedezón tevékenység volt, a detektivfelïgyelö önállóan nyomozást nem indithatott, megbizást nyomozásra rend szerint a bünfenyitö osztály vezetöje adta a detektiúfelïgyelönek. A büncselekmények megelözése, megakadályozása és felderítése érdekében a nyílt eljárások mellett pubatoló eljárásokat alkalmaztak. Utóbbiakat a bűnvádi eljárási ${ }^{258}$ törvény nem részletezte, a bűnügyi nyomozás helyes gyakorlatának végrehajtását a nyomozati utasítás ${ }^{259}$ és annak ügyészségi magyarázata segítette. A puhatoló eljárások közé tartozott a megfigyelés, „besúgók” előzetes alkalmazása, a feltűnés nélkül való érdeklődés és a les. A figyelő, megelőző szolgálat (bűnözés színterein jelenlét) és a puhatoló eljárások alkották a korabeli bủnügyi hírszerzés magját. A puhatoló eljárások célja az igazságszolgáltatás előkészítése volt.

A detektívek képzésének, a detektívtanfolyamoknak az első nyomait már az 1890-es években megtaláljuk Magyarországon. Kétféle tanfolyamot és vizsgát rendszeresítettek: az egyik a detektív, a másik pedig a detektívfelügyelői kinevezés alapjául szolgált. Az egyszerū detektívtanfolyam rendes tárgyai voltak az alaki büntetőjog, kriminalisztika, a kihágások és a rendőri bíráskodás, az államrendészet, a közigazgatási alapismeretek, a szervezet és szolgálati szabályzat, az elsősegélynyújtás. A rendes előadásokat a speciális előadások és gyakorlati bemutatások egészítették ki a mindenkori tanterv szerint." ${ }^{260}$ A detektívek próbaideje 1 év volt, ezt követően került sor véglegesítésükre vagy indokolás nélkül elbocsáthatók voltak. A századforduló időszakában a Ludovika Akadémián elindult csendőrségi és a fôvárosi rendőrség képzése, egymásra épülő szaktanfolyamai európai színvonalúak voltak.

A két világháború közötti időszakban már nemzetközi kapcsolatok alakultak ki a különböző rendvédelmi szervezetek között és elvétve előfordult, hogy magyar tisztek tanultak külföldi

\footnotetext{
257 NYESTE Péter: A bűnüldözési célú titkos információgyűjtés története, rendszerspecifikus sajátosságai, szektorális elvei. In: Szabó Csaba (szerk.) Studia Doctorandorum Alumnae, Pytheas Kiadó, Bp., 2019. pp. 213 441. https://doi.org/10.23715/SDA.2019.2.2

258 1896. évi XXXIII. törvénycikk, a bűnvádi perrendtartásról

259 130,000/99 B.M. számú körrendelet a nyomozó rendőri közegek és hatóságok részére. MAGYAR István: A bűnügyi nyomozás tárgyában a nyomozó rendőri hatóságok és közegek részére 130,000/99. B.M. számú körrendelettel kiadott utasítás magyarázata. Budapest, 1900.

${ }^{260}$ KESERŰ István: A rendvédelmi szervek tiszti utánpótlása és tisztképzése a dualizmus időszakában. ORFK OKK, Rendvédelem-történeti füzetek,1993/4. szám. pp. 109-126: 121.
} 
rendvédelmi tanintézetekben. (pl. csendőrtisztek Olaszországban, Ausztriában). Külföldi tanulmányutakra és külföldi rendvédelmi küldöttségek látogatására is sor került. ${ }^{261}$

A bűnügyi hírszerzés mellett az állam politikai, kormányzati tevékenységét támogató polgári hírszerzés integrált szervezetrendszere - a politikai jellegú delictumok büntető kódexben történő szabályozásának megfelelően - az 1920-as évektől épült ki hazánkban, melyet elsősorban a rendőrség erre a feladatra kijelölt detektív egységei és a csendőrség erre jogosult nyomozó hatóságai hajtottak végre. A politikai irányú nyomozások összefogására a belügyminiszter 1942-ben létrehozta az Államvédelmi Központot. A szervezet feladata elsősorban a politikai jellegű nyomozások összehangolása volt. A csendőrségi nyomozókhoz tartoztak a baloldali ügyek, a rendőrséghez a jobboldali mozgalmak ellenőrzése, megfigyelése. A nemzetiségi mozgalmakkal közösen foglalkoztak.

Az önálló katonai hírszerzés és elhárítás feladatait 1920-tól a trianoni békediktátum miatt rejtetten a Honvédelmi Minisztérium VI. csoportjának 2 osztálya a HM VI-2. osztály, majd 1938-tól már nyíltan a Honvéd Vezérkar 2. (hírszerző és kémelhárító, 2. vkf.) osztály látta el. A katonai felderítés és elhárítás szorosan együttmúködött a Magyar Királyi Rendőrség szerveivel és a Magyar Királyi Csendőrség Központi Nyomozó Osztályával. ${ }^{262}$ A katonai elhárítás és a csendőrség között szoros együttmúködés alakult ki még képzési téren is. ${ }^{263}$

\section{A hazai bűnügyi hírszerzés jellemzői a II. világháborútól a rendszerváltásig}

A második világháborút követően kialakult vesztes politikai helyzetben fokozatosan átalakult az ország több évszázados polgári hagyományokon nyugvó társadalmi, politikai rendszere. Az új, szovjet típusú, ideológiai alapú társadalmi, politikai átalakulás nem is lehetett kérdéses. A bűnügyi hírszerző tevékenység szervezete, céljai, lényege is átalakult. Az eddigi igazságszolgáltatási tevékenységet előkészítő puhatoló eljárások titkos operatív tevékenységek elnevezést kaptak és szovjet mintára felállították az ideológiai, politikai rendszert kiszolgáló államvédelmi, állambiztonsági egységeket. A titkos operatív tevékenységeknek nem volt igazságszolgáltatás előkészítő szerepe, a nyomozás törvényességi felügyeletét ellátó ügyészség nem is tudhatott ezekről. A titkos operatív tevékenységet szabályozó legmagasabb szintű, titkos minisztertanácsi norma (1/1975-ös MT elnökhelyettesi utasítás) alapján a belügyminisztérium és szerveinek a titkos operatív tevékenysége nem állt az ügyészség felügyelete alatt.

A bűnüldözési célú titkos operatív eszközök, módszerek alkalmazása másodlagossá vált az állambiztonsági titkos operatív eszközök, módszerekkel szemben és a bűnüldözési jellegű titkos operatív tevékenység is elsősorban a társadalmi tulajdon elleni bűnözésre koncentrált. Az állam elleni (a pártállami, kommunista ideológia elleni) és szervezett formájú bűncselekmények felderítése, megelőzése érdekében a büntetőeljárás elrendelését megelőzően végrehajtható volt egy titkos operatív felderítési, bizonyítási, vizsgálati szakasz, amely egy alternatív titkos büntetőeljárásként volt felfogható. ${ }^{264}$ A vizsgálók a „titkos büntetőeljárás” adatai alapján eldöntötték, hogy megindítják-e a „nyílt” büntetőeljárást (realizálják a titkosan beszerzett adatokat), vagy más módon (pl. pressziós

\footnotetext{
${ }^{261}$ BODA József: A nemzetközi oktatás és képzés története a magyar rendvédelmi szervezeteknél. Rendvédelemtörténeti Füretek, 2007/16. szám. pp. 33-46: 33.

262 BODA József- ReGÉNYI Kund: Önálló magyar hírszerzés és elhárítás (1918-1945). In: BoDA JózsefREGÉNYI Kund (szerk.): A hírszerzés története az ókortól napjainkig. Dialog Campus, Bp., 2019. pp. 116-120: 118.

263 DOBÁK Imre: Adalékok a 2. VKF osztály képzéstörténeti kérdéseihez... Felderitő Szemle, 2014/2. szám. pp. 105-116: 106.

264 A titkos operatív felderítési, bizonyítási vizsgálati szakaszhoz lásd VÖRÖs Géza: Az állambiztonság hálózaton kívüli információszerző technikái. Levéltári Szemle, 2013/1. szám. pp. 19-30.
} 
ügynökbeszervezéssel) realizálnak, azaz hasznosítják az információkat. Az állambiztonsági és bűnüldöző hatóság önállóan döntött arról, hogy hogyan szerzik be később a büntetőeljárás keretei között a „titkos büntetőeljárás” által megismert, rögzített adatokat, információkat, azaz „a titkos eljárási eredményt”. A rendészet része volt a proletárdiktatúra államgépezetének, ezért osztozott annak a monolitikus hatalmi központ általi kiszolgáltatottságában ${ }^{265}$.

A bűnügyi és állambiztonsági hírszerzés utánpótlását biztosító, a politikai rendszert kiszolgáló államvédelmi, állambiztonsági és rendőrtiszti képzés 1949-ben a budapesti Rendőrakadémia helyébe lépő Rendőrtisztképző Iskolában, illetve az államvédelmi tisztek képzése 1950-től a Dzserdzsinszkij Államvédelmi Szakiskolában történt. ${ }^{266}$ 1957-tôl a Rendôrtiszti Akadémia megalakulásáig (1959-ig) a BM Dzserdzsinszkij Tisztképző Iskola biztosítja az államvédelmi, bűnügyi és közrendvédelmi tiszti utánpótlást, majd 1971-ben kezdte meg működését a Rendőrtiszti Főiskola. ${ }^{267}$

\section{A hazai bủnügyi hírszerzés jellemzői a rendszerváltástól napjainkig}

A rendszerváltást követően, 1990-ben kirobbant ún. Duna-gate botrány után a titkosszolgálatok, és a bűnüldöző szervek „különleges” titkos információgyújtő tevékenységének szabályozására az országgyúlés megalkotta az 1990. évi X. törvényt, a különleges titkosszolgálati eszközök és módszerek engedélyezésének átmeneti szabályozásáról. A külső engedélyhez kötött titkos eszközök, módszereken kívüli, belső engedélyezésű bủnüldözési (és állambiztonsági) célú titkos módszerek, eszközök alkalmazására továbbra sem volt törvényi szintű szabályozás.

Egy hosszú előkészítő munka után született meg az 1994. évi XXXIV. Rendőrségről szóló törvény, melynek külön fejezete (VII.) szabályozta a „bűnügyi célú” titkos információgyűjtést, ami a korábban puhatoló eljárásoknak, majd később titkos operatív eszközöknek, módszereknek nevezett tevékenységek új, törvényi szintű elnevezése lett. Ezzel a bűncselekmények megelőzése, felderítése és bizonyítása új, megismerhetô, jogilag szabályozott lehetőségekhez jutott, csekély külső kontrollal. Azonban a korábbi diktatórikus rendszer logikájához hasonló felderítési, bizonyítási tevékenységek titkos gyakorlata részben megmaradt. A büntetőeljárás nem szabályozta, de megengedte a titkosan szerzett információk felhasználását a büntetőeljárásban a csekély külső kontrol ellenére. „Bár e tevékenységre a törvényi szintü szabályozás felhatalmazást adott, részletszabályozása változatlanul belső normákban és utasításokban történt. Az ismeretanyag nyílt és titkos összetevői indokolt módon okot adtak egyfajta elkülönítésre, hiszen az állampolgárok előtt a titkos információgyűjtés, mint lehetőség nem titkolt, ugyanakkor a részletszabályozás, a konkrét alkalmazás továbbra is titkot képezett, és ez együtt járt a titokvédelemből fakadó korlátozásokkal.",268

\footnotetext{
265 KORINEK László: A rendőrség pártirányítása 1956-1989. Rendészeti Szemle, 2006/10. szám. pp. 55-67.

$260 \mathrm{Az}$ államvédelmi, állambiztonsági és rendőrtiszti képzés második világháború utáni megindításához lásd CZENE-POLGÁR Viktória: „A dolgozó nép hazájának védőkarja”: Rendőrképzés 1945 és 1948 között. In: SzEKÉR Nóra et al. (szerk.) Utak a Teleki térről. Esszék és tanulmányok a 75 éves M. Kiss Sándor tiszteletére. Antológia, Lakitelek, 2018. pp. 61-68., valamint CZENE-POLGÁR Viktória: „Az intellektuális munkaerő arányszámát emeljük” - Tudásmenedzsment a második világháború utáni rendvédelmi szerveknél. In: CZENEPOLGÁr Viktória, ZsÁMBOKINÉ FICSKOVSZKY Ágnes (szerk.) Innováció, elektronizáció, tudásmenedzsment. Magyar Rendészettudományi Társaság Vám- és Pénzügyőri Tagozat, Bp., 2018. pp. 59-69.

267 BUDAHÁzi Árpád (szerk.): Jubileumi évkönyv 40 éves a Rendőrtiszti Főiskola 1971-2011. Rendőrtiszti Főiskola, Bp., 2011. pp. 17-24.

268 SZENDREI Ferenc: A rendészeti célú titkos információgyüjtés. Rendôrségi Tanulmányok, 2020/3. pp. 58-80: 62.
} 
A belső, minősített normák alapján a titkos információgyűjtés a rendszerváltást megelőző eljárási rendhez hasonlóan titkos információ ellenőrző és titkos nyomozás szakaszra tagolódott, amelyek továbbra is azt eredményezték, hogy a nyomozó hatóság önállóan, saját döntése szerint elrendelhetett és végrehajthatott egy bűnügyi relevanciájú információ ellenőrzését követő a gyanú megállapítására és bizonyítékok meglétének, hollétének felkutatására irányuló titkos nyomozást. Tekintettel arra, hogy a felderítő szerv az ilyen bủnügyi célú titkos információgyüjtését minősítette (titkosította), ezért később minősítôként eldönthette, hogy azt megosztja-e a büntetőeljárásra rendelkezési jogot gyakorló ügyészséggel, vagy egyéb feladatai ellátása érdekében más módon hasznosítja az ismereteket, vagy akár elvesznek a beszerzett információk. A bűnügyi célú titkos információgyüjtés eredménye büntetőeljárásban csak a minősítő döntését követően volt felhasználható hosszadalmas eljárást követően. A büntetőeljárásban szabályozott adatszerzés eredményének felhasználása már rugalmasabb eljárási rendben történt, de a beszerzett minősített adatok összefoglaló jelentésben rögzítése és a mellékelt tárgyi bizonyítási eszközök ebben az esetben is csak minősítéstörlési döntést követően voltak a büntetőeljárásban felhasználhatók. A titkos információgyűjtés a büntetőeljárástól elkülönült eljárási rendet jelentett, az információknak csak egy részét használták fel, és csak az ügyészség elé tárt eredmény hasznosult a büntetőeljárásban.

A felderítés, nyomozás folyamatossága és az információvesztés elkerülése érdekében újra kellett gondolni az információgyűjtés és -ellenőrzés folyamatát, eljárási kereteit. Konkrét bűncselekményre utaló információk ellenőrzését, majd az ellenőrzött adatok alapján folytatható speciális nyomozási tevékenységek ${ }^{269}$ alkalmazhatóságának folyamatosságát meg kellett teremteni a nyomozás minden fázisában.

Az új büntetőeljárási törvény ${ }^{270}$ a bủncselekmények felderítése és bizonyítása érdekében folytatható titkos információgyűjtés szabályait teljesen integrálta a büntetőeljárási törvénybe. Ezzel a párhuzamos, büntetőeljáráson kívüli titkos információszerzés és a büntetőeljárás keretében folytatott titkos-, illetve egyéb adatszerzés szabályozásának a szétválasztottságából, eltérő törvényekben, különböző megfogalmazású szövegezéssel való elhelyezéséből fakadó gyakorlati, jogalkalmazási probléma vált elkerülhetővé.

A törvény szakított azzal a szemlélettel, amely a titkos információgyüjtést és a titkos adatszerzést elkülönült eljárási folyamatként tekintette. A titkos információgyüjtés és titkos adatszerzés különleges eszközei és módszerei a bizonyítási eszközök és cselekmények katalógusát gazdagítják, egységesen szabályozva és törvényi szinten biztosítva a szükségesség-arányosság-célszerűség követelményéhez igazodó kivételes alkalmazás feltételrendszerét is.

A kialakított eljárási rendszer biztosítja annak lehetőségét, hogy nyomozás elrendelését megelőzően, de már a büntetőeljárás keretein belül a bűncselekmények gyanújának megállapítása vagy kizárása érdekében, rövid határidőn belül proaktív előzetes felderítés legyen alkalmazható. ${ }^{271}$

\footnotetext{
${ }^{269}$ NYESTE Péter: Speciális nyomozási tevékenységek az Európai Unió egyes tagállamaiban. Belügyi Szemle, 2016/3. szám. pp. 16-43. https://doi.org/10.38146/BSZ.2016.3.2

270 2017. évi. XC. törvény a büntetőeljárásról

${ }^{271}$ NYESTE Péter - SZENDREI Ferenc: A bűnügyi hírszerzés kézikönyve. Dialog Campus Kiadó, Bp. 2019. p. 88.
} 


\section{A hazai bűnügyi hírszerzés meghatározása, részei}

A modern bünügyi hírszeręést az alaptörvényben megjelenített rendészeti és bủnüldözési célok (a közbiztonság, a közrend és az államhatár rendjének védelme, a bűncselekmények megakadályozása, felderítése,) elérése érdekében, a rendészeti ágazati törvényekben megjelenített feladatszabás és a büntetőeljárás nyomozási feladatai érdekében végrehajtott, a magán- és családi élet, a magánlakás és levelezés tiszteletben tartásához és ehhez szorosan kapcsolódó információs önrendelkezéshez, az információáramlás szabadságához és a személyes adatok védelméhez füződő jogot is korlátozható, proaktív információszerző és elemző tevékenységként jellemez̧etjük ${ }^{272}$.

A bűnügyi hírszerzésnek alapvetően stratégiai, taktikai illetve nyomozást támogató feladatai lehetnek.

- A stratégiai célú bünügyi hírszerezés kiindulópontja a stratégiai búnügyi elemzés ${ }^{273}$, amely meghatározott bűnügyi elemzési módszerekkel a bűnözés terjedelmének, dinamikájának és struktúrájának, valamint egyes bűncselekmények jellemzőinek, elterjedtségének hosszabb távon érvényesülő mintázatát, tendenciáit vizsgálja. A stratégiai bűnügyi elemzésnek folyamatosan figyelemmel kell kísérnie a bűnözés nemzetközi és hazai helyzetében bekövetkezett vagy várhatóan bekövetkező lényegi változásokat is. A stratégiai célú elemzés lehetőséget teremt különböző tendenciák vizsgálatával, előrejelzések, prognózisok készítésére. Ezáltal a kormányzati irányítás és a rendőri vezetés döntés előkészítő mechanizmusában igen fontos szerepet tölt be. ${ }^{274} \mathrm{~A}$ stratégiai bűnügyi hírszerzés célja a folyamatos stratégiai elemzések alapján megfogalmazott aktuális hírigények kielégítése és ezzel a stratégiai döntéshozatal megalapozása.

- Azoperativ vagy ",taktikainak” nevezett bünügyi birszerzés kiindulópontja a folyamatos taktikai bűnügyi elemzés ${ }^{275}$, amely a rendőrségi adatokra alapozott, a bünözés rövidtávú fejlódésének vizsgálatára irányuló, a közterületi és a bünügyi tevékenység hatékonyságát célzó, az erők és források optimális elosztását - többnyire lokális szinten - megalapozó vezetői döntések támogatásához alkalmazott elemzési formák összessége. Az értékelés beazonosítja azokat a kiemelkedő, új bűnügyi mintákat, trendeket, kockázatokat, veszélyeket amelyek figyelmet, érdekelnek és további elemzést követően intézkedések bevezetését alapozhatják meg. A taktikai hírszerzés célja az egyedi és konkrét bűnügyi problémák azonnali megelőzését, kezelését, megoldását hivatott szolgálni. Ide tartoznak a bűnügyi hírszerzés infrastruktúrájának fenntartása érdekében (pl. együttmúködő, fedett nyomozó alkalmazása, védelme) végezhetô hírszerző tevékenységek, de a kockázatelemzéseken alapuló személy, objektumvédelmi bűnügyi hírszerző tevékenységek is.

- A nyomozást támogató bünügyi birszerzés kiindulópontja a nyomozást támogató elemzés ${ }^{276}$, amely az egyes büntetöeljárások és a titkos információgyüjtések, valamint leplezett eszloözöök alkalmazása során beszerzett adatok vizsgálatával foglalkozó tevékenység, mely segítséget nyújthat az ismeretlen elkövető felderítéséhez, a nyomozási cselekmények tervezéséhez, az eljárásokban részt vevő személyek és a hozzájuk kapcsolható objektumok közti kapcsolatok felismeréséhez, a szervezett bűnelkövetői csoportok és tevékenységük felderítéséhez, a csoportok ellen folytatott bűnüldöző munka feladatainak meghatározásához. A nyomozást támogató bűnügyi hírszerzésnek a feladata az egyedi és konkrét bűncselekmények, illetve arra utaló elemzett információk, adatok

\footnotetext{
${ }^{272}$ NYESTE Péter - NAGY Ivett: A bűnügyi hírszerzés az elméletben és a gyakorlatban. Rendôrségi Tanulmányok 2021/1. szám. pp 1-18.

273 23/2018 (VI.21.) ORFK Utasítás a Bűnügyi Elemzési Szabályzatról 2.』 n) pontja

274 ISTVANOVSZKI László: Bűnelemzés a modern bűnüldözésben. Patrocínium, Bp., 2012. p. 35.

275 23/2018(VI.21.) ORFK Utasítás a Bűnügyi Elemzési Szabályzatról 2.〕o) pontja

276 uo. 2.\ k) pontja
} 
alapján meghatározott további nyomozást támogató hírigények információkkal és eredménytermékekkel (lehetséges bizonyítási eszközök) történő kiszolgálása. A sqervęett bünözói csoportok és tevékenység̈̈̈ felderítése, bomlasztása részben stratégiai, részben taktikai és végül nyomozást támogató bünügyi hírszerzést is igényel.

\section{Egyes rendészeti modellek}

A „probléma-orientált rendészete" (angol rövidítéssel: POP) koncepcióját Herman Goldstein eredetileg az esemény-orientált, reaktív rendészet kritikájaként és alternatívájaként dolgozta ki. Gyakran SARA-modellnek is nevezik: Scanning, azaz vizsgálódás (a rendszeresen előforduló problémák után), Analysing, azaz elemzés (a beavatkozáshoz elégséges okoké), Responding, azaz reagálás (célzott beavatkozás útján), és Assessment, azaz értékelés (a megvalósítás folyamatának és eredményének felmérése). A modellnek kulcs eleme a különböző rendészeti és civil szervekkel, szervezetekkel való szoros partneri együttmúködés kialakítása. A problémaorientált rendészet segítségével jobban meg lehet érteni a társadalmi folyamatokban gyökerező kriminalitást és előre lehet jelezni trendek, változásokat, de az információkat csak szoros együttműködéssel és komoly elemző munkával lehet elérni.

A birszerzés alapú rendészet számos jellemzőjében megegyezik a fent említett stratégiákkal, néhány tekintetben viszont eltér azoktól. ${ }^{277} \mathrm{Ha}$ összevetjük a közösségi és a problémaorientált rendészettel, akkor kitűnik, hogy a hírszerzés alapú rendészet közelebbről fókuszál a bűnüldözésre, valamint a büntető igazságszolgáltatás eszközeire és céljaira. A hírszerzés alapú rendészet a bűnügyi hírszerző elemzés szigorú döntéshozatali eszközként való alkalmazása azzal a céllal, hogy hatékony rendészeti stratégiákon keresztül előmozdítsa a bűncselekmények számának csökkenését és a bűnmegelőzést. ${ }^{278} A$ birsžerzés alapú rendészetet sikeresen alkalmazzák az előforduló főbb bűnügyi problémák ellen, de önmagában nem elég hatékony az új bűnelkövetési minták, folyamatok feltárásában és a válaszlépések megfogalmazásában. Az ilyen folyamatok megfelelő feltárását és a hatásos fellépést a probléma orientált rendészet biztosíthatja. ${ }^{279}$

A kö̈össégi rendészet az egyike azoknak a rendészeti elméleteknek, amelyeket rendészeti koncepcióként és stratégiaként az USA-ban dolgoztak ki, majd a 80-as években Európába áthoztak. ${ }^{280} \mathrm{~A}$ közösségi rendészet alapgondolata az, hogy a rendőrséget decentralizálva közelebb kell hozni a helyi lakóközösségekhez, ehhez pedig a körzeti őrszobák hálózatára támaszkodva a rendőröket személyesen is össze kell ismertetni a lakossággal, fokozni kell a rendőrség láthatóságát a köztereken, továbbá a közösséget be kell vonni azoknak a problémáknak a meghatározásába, amelyeket a rendőrség azután a társszervekkel és a lakossággal együttmúködve megold. A közösségi rendészet inkább megelőző jellegű, mint reaktív, ugyanis a fő cél a lakosság biztonságérzetének növelése."281 Önmagában azonban a

277 Tilley, Nick: Community Policing, Problem-oriented Policing and Intelligence-Led Policing. In. NeWBurn, Tim (ed.): Handbook of Policing. Cullompton, Willan, 2003. pp. 311-339.

278 RATCLIFFe, Jerry H.: Intelligence-led Policing. Cullompton, Willan, 2008. p. 17.

${ }^{279}$ KARN Jacqui: The role of the Police in Reducing Crime. In: KARN Jacqui (ed.) Policing and crime reduction. The evidence and its implications for practice. Police Effectiveness in a Changing World Project, The Police Foundation, London, 2013. pp. 9-25.

280 SkOGAN, Wesley G.: Community Policing: Can it work? Wadsworth, Thomson Learning, 2004. pp. 57-75; és HolmberG, Lars: Policing and the Feeling of Safety: the Rise (and Fall?) of Community Policing in the Nordic Countries. Journal of Scandinavian Studies in Criminology and Crime Prevention, 5(2) pp. 205-219. https://doi.org/10.1080/14043850410010702

281 JASCHKE, Hans-Gerd et al.: Final Report on a European Approach to Police Science (PGEAPS). CEPOL, 2007. p. 63. 
megnövelt rendőri jelenlét bűncselekmény csökkentő hatása nem igazolható meggyőzően. ${ }^{282}$ Egyes tanulmányok szerint 10\%-os rendôri jelenlét fokozásnak 3\%-os bűncselekmény csökkentő hatása lehet a kisebb értékű vagyon elleni és kapcsolódó bűncselekményekre, ${ }^{283}$ de az erőszakos bűncselekményekre gyakorolt hatása már nem egyértelműen kimutatható. A közösségi rendészet hatásfokát, a rendőri intézkedések elfogadását, a lakossággal való partneri viszony kialakítását nehezítheti a lakosság eltérő nemzetiségi összetételéből, eltérő kulturális beállítottságából fakadó változása. ${ }^{284}$ A közösségi rendészet így jó válasz lehet a lakosság biztonságérzetének a növelésére, de bűncselekmény csökkentő hatása csak abban az esetben tud tartós vagy hatékonyabb lenni, ha az a célirányosan beszerzett információk elemzését követően alkalmazott célirányos fokozott rendőri jelenléttel párosul.

A bűnügyi hírszerzési modell jogszabályi szintű megjelenítése és alkalmazása angolszász területen terjedt el elsősorban, de az Europol Fedett Humán Erőforrások Alkalmazásának Kézikönyve ${ }^{285}$ is részletesen tárgyalja a bűnügyi hírszerzés humán eszközei alkalmazásának a szabályait ajánlásként a rendvédelmi szervek részére. A brit Nemzeti Hírszerző Modellen ${ }^{286}$ kívül az Egyesült Államok szövetségi jogszabályai is részletesen tárgyalják a bűnügyi hírszerző rendszerek múködésének alapelveit. (Code of Federal Regulations 28-as cím 23 része „a Bűnügyi hírszerző rendszerek múködési szabályozása (Criminal intelligence systems operating policies, CFR Part 23)." ${ }^{287}$ A jogszabály 23. része részletesen leírja a bűnüldözési hírszerző rendszerek múködésének szabályait, amely tartalmazza a célkitűzéseket, alkalmazhatóságot, múködési alapelveket, működési irányelveket, a rendszert ellenôrző, auditáló tevékenységeket. A fenti dokumentumok elemzése alapján a bűnügyi hírszerzési képesség fejlesztésének alaplépései a megfelelő szervezeti elem (bűnügyi információs egység) felállítása, az egyes munkakörökre a specialisták, szakemberek kiválasztása, folyamatos képzés, oktatás, humán és anyagi, technikai erőforrások biztosítása, a hírszerzési tudatosság, hírszerzési prioritási pontok terjesztése a szervezeten belül.

\section{Hazai bünügyi hírszerzési szervezeti modellek}

A rendőrség bűnügyi hírszerzéssel foglalkozó szervezeti szintű megoldásai igen változatos képet mutatnak. A hazai gyakorlatban a korábbi törvényi szabályozási keretek között is és a hatályos jogszabályok alapján is különböző szakspecifikus hírszerző szervezeti modelleket alkalmaztak(nak). A NAV Bűnügyi Főigazgatóságánál a szakterület specialitásainak megfelelően és a nemzetközi tapasztalatok figyelembevételével már évek óta kifejlesztették a bủnügyi hírszerző modelljüket (pl. kontroller személy alkalmazása, lokális szinten csak eseti adatközlők foglalkoztatása stb.).

Az általános rendőri feladatok ellátására létrehozott szervnél a KR Nemzeti Nyomozó Iroda, illetve a Budapesti Rendőr-főkapitányság, mint nagyobb, koncentrált bủnügyi

\footnotetext{
282 BRADFORD, Ben: Police numbers and crime rates - a rapid evidence review. HMIC, London, 2011. p. 7.

${ }^{283}$ LEVITT, Steven D.: Using Electoral Cycles in Police Hiring to Estimate the Effect of Police on Crime. The American Economic Review, 87(3), 1997. pp. 270-290. https://www.jstor.org/stable/2951346

${ }^{284}$ BotToms, Antony - TANKeBE, Justice: Beyond Procedural Justice: A Dialogic Approach to Legitimacy in Criminology. Journal of Criminal Law and Criminology, 102(1), 2012. pp. 112-170. https://scholarlycommons.law.northwestern.edu/jclc/vol102/iss1/4

285 EUROPOL: Covert Human Intelligence Source Handling, European Union Manual on Common Criteria and Priciples, Europol, 2012. p. 8.

286 ACPO: Guidance on the National Intelligence Model. Association of Chief Police Officers, Bedford, 2005. https://whereismydata.files.wordpress.com/2009/01/national-intelligence-model-20051.pdf

${ }^{287}$ Criminal intelligence systems operating policies, CFR Part 23.

https://www.govinfo.gov/app/details/CFR-2015-title28-vol1/CFR-2015-title28-vol1-part23 (letöltve: 2020.11.06.)
} 
feladatokat ellátó egységek alkalmaznak elsősorban szervezeti szinten elkülönített és specializált integrált hírszerző egységeket (humán hírszerzés, elemzés, ügyfeldolgozás).

A bűnügyi hírszerzés titkos információgyújtő feladatait a rendőrség felderítő egységei végzik, azonban a leplezett eszközök alkalmazását több területi szervnél már más szervezeti elemek is folytatják (pl. gazdaságvédelemi, bűnügyi osztály) és a vonatkozó elemzéseket szintén más szervezeti elemek látják el. Vannak olyan szervezeti megoldások is, hogy a területi szervek látják el a helyi szervek bűnügyi hírszerzési igényeit is, de arra is vannak példák, hogy nagyobb eszköz és humánerőforrás igényes múveleteket a területi szervek bűnügyi hírszerzői közösen hajtják végre a helyi szervekkel. Azaz nincs egy egységes, de a helyi sajátosságoknak is megfelelő integrált bűnügyi hírszerzési modell.

\section{Összegzés}

A tanulmányomban bemutattam a bűnügyi hírszerzés adott szakmatörténeti korszakainak a legfontosabb jellemzőit, a jogszabályi környezetet. Áttekintettem néhány külföldi rendészeti és hírszerzési modellt és a jelenlegi hazai bűnügyi hírszerzés jellemző szervezeti megoldásait tárgyaltam, továbbá elemeztem a büntetőeljárás új felderítési, bizonyítási szemléletét. Végezetül megállapítottam, hogy a hatékony, egységes, ugyanakkor szervezetre szabott, ugyanazt a végrehajtási, ügyfeldolgozási, ellenőrzési protokollt követő integrált bűnügyi hírszerzési modell kidolgozása és szervezeti elemi szintű kialakítása továbbra is kihívást jelent a rendészettudományi kutatók és a rendôrség bủnügyi szolgálati ágának a szakemberei részére.

\section{Felhasznált irodalom}

[1] 130,000/99 B.M. számú körrendelet a nyomozó rendőri közegek és hatóságok részére. MAGYAR István: A bűnügyi nyomozás tárgyában a nyomozó rendőri hatóságok és közegek részére 130,000/99. B.M. számú körrendelettel kiadott utasítás magyarázata. Bp., 1900.

[2] 1896. évi XXXIII. törvénycikk, a bủnvádi perrendtartásról

[3] 2017. évi. XC. törvény a büntetőeljárásról

[4] 23/2018 (VI.21.) ORFK Utasítás a Bűnügyi Elemzési Szabályzatról

[5] 23/2018(VI.21.) ORFK Utasítás a Bűnügyi Elemzési Szabályzatról

[6] ACPO: Guidance on the National Intelligence Model. Association of Chief Police Officers, Bedford, 2005.

https://whereismydata.files.wordpress.com/2009/01/national-intelligence-model20051.pdf

[7] BODA József - REGÉNYI Kund (szerk.): A hírszerzés története az ókortól napjainkig. Dialog Campus, Bp., 2019.

[8] BODA József - REGÉNYI Kund: Önálló magyar hírszerzés és elhárítás (1918-1945). In: BODA József - REGÉNYI Kund (szerk.): A hírszerzés története az ókortól napjainkig. Dialog Campus, Bp., 2019. pp. 116-120.

[9] BODA József et al. (szerk.): Rendészettudományi szaklexikon. Dialog Campus, Bp., 2019.

[10] BODA József: A nemzetközi oktatás és képzés története a magyar rendvédelmi szervezeteknél. Rendvédelem-történeti Füzetek, 2007/16. szám. pp. 33-46.

[11] BotToms, Antony - TAnKeBE, Justice: Beyond Procedural Justice: A Dialogic Approach to Legitimacy in Criminology. Journal of Criminal Law and Criminology, 102(1), 2012. pp. 112-170. https://scholarlycommons.law.northwestern.edu/jclc/vol102/iss1/4 
[12] BRADFORD, Ben: Police numbers and crime rates - a rapid evidence review. HMIC, London, 2011.

[13] BUDAHÁZI Árpád (szerk.): Jubileumi évkönyv 40 éves a Rendőrtiszti Főiskola 19712011. Rendőrtiszti Főiskola, Bp., 2011. pp. 17-24.

[14] Criminal intelligence systems operating policies, CFR Part 23. https://www.govinfo.gov/app/details/CFR-2015-title28-vol1/CFR-2015-title28vol1-part23 (letöltve: 2020.11.06.)

[15] CZENE-POLGÁR Viktória: „A dolgozó nép hazájának védőkarja”: Rendőrképzés 1945 és 1948 között. In: SZEKÉR Nóra et al. (szerk.) Utak a Teleki térről. Esszék és tanulmányok a 75 éves M. Kiss Sándor tiszteletére. Antológia, Lakitelek, 2018. pp. 61-68.

[16] CZENE-POLGÁR Viktória: „Az intellektuális munkaerő arányszámát emeljük” Tudásmenedzsment a második világháború utáni rendvédelmi szerveknél. In: CZENE-PolgÁr Viktória, ZsÁmbOKINÉ FICSKOvSZKY Ágnes (szerk.) Innováció, elektronizáció, tudásmenedzsment. Magyar Rendészettudományi Társaság Vám- és Pénzügyőri Tagozat, Bp., 2018. pp. 59-69.

[17] DoBÁK Imre: Adalékok a 2. VKF osztály képzéstörténeti kérdéseihez... Felderitő Szemle, 2014/2. szám. pp. 105-116.

[18] EurOPOL: Covert Human Intelligence Source Handling, European Union Manual on Common Criteria and Priciples, Europol, 2012.

[19] Holmberg, Lars: Policing and the Feeling of Safety: the Rise (and Fall?) of Community Policing in the Nordic Countries. Journal of Scandinavian Studies in Criminology and Crime Prevention, 5(2) pp. 205-219. https://doi.org/10.1080/14043850410010702

[20] IstVANOVSZKI László: Bűnelemzés a modern bűnüldözésben. Patrocínium, Bp., 2012.

[21] JASCHKE, Hans-Gerd et al.: Final Report on a European Approach to Police Science (PGEAPS). CEPOL, 2007.

[22] KARN Jacqui: The role of the Police in Reducing Crime. In: KARN Jacqui (ed.) Policing and crime reduction. The evidence and its implications for practice. Police Effectiveness in a Changing World Project, The Police Foundation, London, 2013. pp. 9-25.

[23] KESERƯ István: A rendvédelmi szervek tiszti utánpótlása és tisztképzése a dualizmus időszakában. ORFK OKK, Rendvédelem-történeti füzetek,1993/4. szám. pp. 109-126.

[24] KORINEK László: A rendőrség pártirányítása 1956-1989. Rendészeti Szemle, 2006/10. szám. pp. 55-67.

[25] LEvitT, Steven D.: Using Electoral Cycles in Police Hiring to Estimate the Effect of Police on Crime. The American Economic Review, 87(3), 1997. pp. 270-290.

https://www.jstor.org/stable/2951346

[26] NyESTE Péter - NAGY Ivett: A búnügyi hírszerzés az elméletben és a gyakorlatban. Rendôrségi Tanulmányok, 2021/1. szám. pp 1-18.

[27] NyESTE Péter - SZENDREI Ferenc: A bűnügyi hírszerzés kézikönyve. Dialog Campus, Bp. 2019. p. 88.

[28] NYESTE Péter: A bűnüldözési célú titkos információgyűjtés története, rendszerspecifikus sajátosságai, szektorális elvei. In: SZABÓ Csaba (szerk.) Studia Doctorandorum Alumnae, Pytheas Kiadó, Bp., 2019. pp. 213-441. https://doi.org/10.23715/SDA.2019.2.2

[29] NYESTE Péter: Speciális nyomozási tevékenységek az Európai Unió egyes tagállamaiban. Belügyi Szemle, 2016/3. szám. pp.16-43. https://doi.org/10.38146/BSZ.2016.3.2

[30] RATCLIFFE, Jerry H.: Intelligence-led Policing. Cullompton, Willan, 2008. 
[31] Skogan, Wesley G.: Community Policing: Can it work? Thomson Learning, Wadsworth, 2004. pp. 57-75.

[32] SZENDREI Ferenc: A rendészeti célú titkos információgyújtés. Rendörségi Tanulmányok, 2020/3. pp. 58-80.

[33] Tilley, Nick: Community Policing, Problem-oriented Policing and Intelligence-Led Policing. In. NEWBuRN, Tim (ed.): Handbook of Policing. Cullompton, Willan, 2003. pp. 311-339.

[34] VÖRÖS Géza: Az állambiztonság hálózaton kívüli információszerző technikái. Levéltári Szemle, 2013/1. szám. pp. 19-30.

\section{Lektor}

Csaba Zágon, Dr., PhD., adjunktus, pénzügyőr őrnagy,

Nemzeti Közszolgálati Egyetem Rendészettudományi Kar, Vám- és Pénzügyôri Tanszék

csaba.zagon@uni-nke.hu

és

Szendrei Ferenc, Dr., tanszékvezető egyetemi docens, rendôr ezredes, rendőrségi főtanácsos, Nemzeti Közszolgálati Egyetem Rendészettudományi Kar, Bűnügyi, Gazdaságvédelmi és Kiberbűnözés Elleni Tanszék szendrei.ferenc@,uni-nke.hu 